\title{
USING LIFE STORIES TO TEACH ABOUT RESISTANCE TO APARTHEID
}

\author{
DOI: http://dx.doi.org/10.17159/2223-0386/2016/n15a2 \\ Helen Ludlow \\ Wits School of Education \\ University of the Witwatersrand \\ Helen.Ludlow@wits.ac.za
}

\section{Abstract}

This study investigates the responses of undergraduate history students, who are also student teachers, to the use of the autobiography or biography of an apartheid resister in their third year academic history course. The motivation for using autol biography in the history course has been to get away from a lifeless narrative of apartheid legislation and, for students, somewhat anonymous political movements. It has also become apparent that for some students, their school exposure to apartheid history was dulled by narrow focus and repetition. The study examines the reasons for student choices of their human subject, and how their understanding of apartheid resistance and their feelings about it are affected by engaging with life stories. It also investigates the extent to which the historical thinking and historical sense of these students both shapes and is influenced by their engagement with autol biography as a form of history. It notes significant levels of interest and empathy generated by the study of apartheid resistance through the life stories, as well as notable levels of commitment and enthusiasm in doing the related tasks. There is some evidence of an ability to critique auto/biography as history - as representation; but largely there is an acceptance of the life story of the 'hero of the struggle' they studied as truthful.

Keywords: Autobiography; Biography; Apartheid; Apartheid resisters; Undergraduate History; Historical Thinking.

I think it was a great exercise because one thing that I've noticed with history, we focus on the big ideas, the ideology, the laws that were being passed, and we don't get to talk about how the normal day-to-day people actually reacted to these laws. (Mashudu)

For me apartheid was like black/white. That's how I understood it, but when I actually did this research project you see all different facets of it and what was going on everywhere. So it's not just black and white, white against black or black against white. It was something ... that goes much deeper. That's why people today still feel such pain and suffering. It's because of the ... deep roots ... that suffered basically. (Tertia) 


\section{Introduction}

As apartheid faced its official demise, a number of "struggle" autobiographies and biographies began to be published, most notably Nelson Mandela's Long walk to freedom in 1994. Reading Elinor Sisulu's Walter \& Albertina Sisulu: a biography (1997), I was struck by how this family story of lives under apartheid communicates contexts, identity, beliefs, disagreements and personal choices very powerfully. Wanting students to meet the human face of apartheid resistance, I designed the history assignment that is the subject of this study (Image 1). It is an assignment that has been repeated annually because it seems to me that studying the life story of a person identified as an apartheid resister achieves something important for my students, many of whom will also be teachers of the history of apartheid. This paper presents the results of my first attempt to research this practice. ${ }^{1}$

\section{Image 1: Tasks based on the auto/biography of an Apartheid Resister}

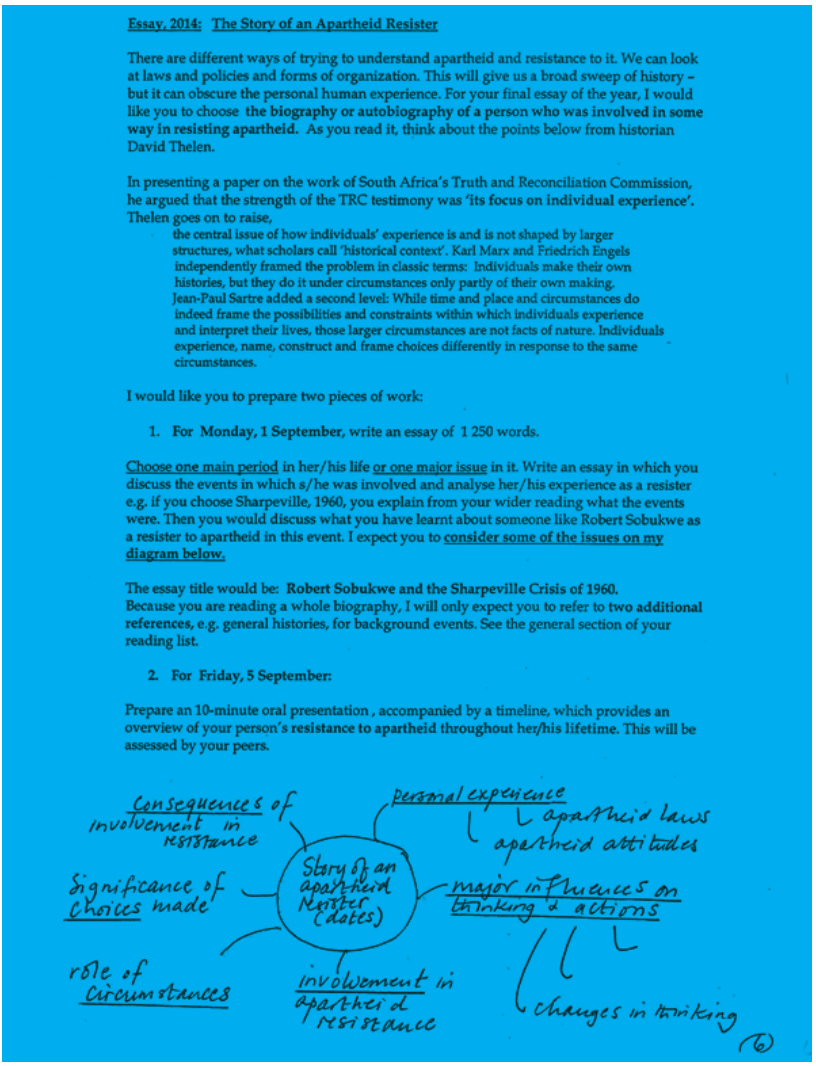

Source: Designed by the author of the article.

1 Ethics Protocol No: 2015ECE013S. 
Students have six weeks to two months to read the auto/biography and prepare the additional tasks. Lectures run concurrently, filling in for students the origins and legal framework of apartheid; phases of implementation; debates about its purpose; as well as the main features of organized resistance.

As outlined in Image 1, there are three tasks in the assignment. The first asks students to choose and read a biography or autobiography of "someone who was involved in some way in resisting apartheid". Having the power to choose their own subject is an important part of the exercise, although I have the right to veto short, simplified popular texts. The purpose of the second task, the essay on a particular event or episode, is to contextualize and amplify the single account without students trying to summarise the whole book At the same time they are asked to work with the Thelen (2002: 181) quotation, which complicates issues of individual experience. The diagram attempts to capture these in framing the essay. For the third task, students are grouped with two peers to present an overview and assess each other's outline of their subject's life story. A "jigsaw" exercise results as I place three resisters of, for example, different backgrounds, ideological commitments, organizational affiliations and so on, in one group (e.g. Joe Slovo, Mamphela Ramphele and Desmond Tutu; or Jay Naidoo, Helen Joseph and Robert Sobukwe).

In October 2015, in order to investigate student responses to this engagement with auto/biography, I conducted an hour-long focus group discussion with seven student volunteers. These B Ed students are in their fourth year of study ${ }^{2}$ and had carried out the assignment the previous year. Four of the students are black - three male (Lungi, Jabu and Mashudu) and one female (Doris). The other three students are also women - one of them coloured (Rachel) and two white (Francine \& Tertia). ${ }^{3}$ The interview was guided by the questions outlined in Appendix B.

\section{Biography and history}

Biography as history is problematic. While popular biography has always remained in demand, for many academic historians (including those in South Africa) the largely empiricist approach of "old" biographies "narrating peoples' lives", particularly those of famous male leaders, became suspect. Jo

2 Wits B Ed students majoring in History have a half course of History as part of Social Science I and II in their first and second years. This is followed by full year course in each of History III and History IV. The students are thus at a second year level in History when engaging with the assignment analysed in this article.

3 These names are pseudonyms. 
Margadant (2000:1) notes that this resulted in "four decades of dormancy" for biography as an academic field. After World War II, collective experience and notions of shared identity as class, race, gender, community and the like became the focus of historical research. Margadant identifies a more recent "ethnographic turn" as creating a view that "social identities take shape within an historically specific cultural setting that imparts meaning to the materiality of life and not the other way around". This, accompanied by post-modern sensibilities, suggests that it is worth paying attention to how individuals "perform the self" and "that a biographical subject has many profiles" (2000:4) depending on the time, place, constraints or opportunities in which that life is performed. There is a "new interest in the politics of identity construction" and a return to biography "since cultural politics are most easily examined as well as empathetically imagined in the individual life" (2000:7-8).

Another new historiographical trend is the "transnational turn". This seeks to displace the "nation" as the essential unit of analysis and to explore those aspects of the human past that transcend any one politically defined territory (Macdonald, 2013). The purpose has been to destabilize the divide between metropole and periphery, and the centrality of the former; to explore networks of ideas, practices, movements of people and so on. This approach seeks to do history "from the outside in", where social history "rewrote history from the bottom up" (Ngai, 2012). Amongst other consequences, this has contributed to a rehabilitation of biography in colonial history (McKenzie, 2008:145):

In the search for methodological solutions to the challenges posed by transnational history, biography has loomed large. Individual lives often slip across boundaries imposed by nationally focused stories in useful and suggestive ways.

This is evident, for example, in the biographical studies in Colonial lives across the British Empire: Imperial careering in the long nineteenth century, examining "some of the ways that individual people made the British Empire and some of the ways that the empire made them" (Lambert \& Lester (eds), 2006:1 in McKenzie, 2008:145). This suggests examining the life of apartheid resisters in exile in new ways, for example, despite their identity within a national struggle.

When this project on apartheid resisters began, there was little awareness of new theoretical engagement with biography, although I was fully mindful of the subjectivity of authors. I return to the implications of this in my concluding comments. The South African auto/biographies that the history students in this study engage with largely fall within the "old" biography paradigm. The 
task is set with the awareness that publishers' priority is marketability, and that authors range from literary scholars and historians, to journalists and the political figures themselves. The proportion of available auto/biographies is weighted towards the political mainstream of the post-1994 dispensation. Because the life stories are the product of detailed research, they are perceived by students epistemologically to be largely "true" narratives of important historical figures. The main purpose of the assignment remains for students, despite the limitations of their texts, to engage in depth with the life story of an apartheid resister.

In his 2002 article, "How the Truth and Reconciliation Commission challenges the ways we use history", David Thelen explores the meaning, for historians, of individual experience as shared at the deeply emotional TRC hearings. The failure of "categories" ... "to capture the vast number of voices and roles that individuals contain within themselves" made him see "individuals as the real actors in history" (2002:175-6) - and in this he echoes Margadant, above. My use of the quotation from Thelen on the assignment (Image 1) was an attempt to guide students' engagement with the text so as to think about the complexity of life experiences (context), beliefs and agency of their subjects. The task itself does not ask about representation, but in the interview (Q.4) I attempted to raise this.

\section{Choice of life story}

Five biographies and two autobiographies had been chosen by the seven students interviewed: Chris Hani: A life too short (Smith \&Tromp. 2009); Thabo Mbeki: The dream deferred (Gevisser, 2007); Bram Fischer: Afrikaner revolutionary new ed (Clingman, 2013); Oliver Tambo: Beyond the Engeli Mountains (Callinicos, 2004); The unlikely secret agent (Kasrils, 2010); In no uncertain terms: A South African Memoir (Suzman, 1993) and Politics in my blood - A memoir (Asmal \& Hadland, 2011).

Motivating the choice of books were both personal concerns and a desire to hear something other than what one student described as the dominant Mandela narrative of resistance. For Lungi, his choice of Chris Hani came from the desire to know about "a comrade" personally and as "another perspective" - that of the SACP (South African Communist Party). Rachel chose Kader Asmal as she wanted to know more about "the coloured or Indian perspective", role and relative advantages or disadvantages. As a woman, 
Tertia chose Helen Suzman because she was a woman (though admitted her choice was also by default - no-one else had chosen Suzman). Mashudu felt that "the story of women in the struggle has been ignored", was annoyed by the "over-politicization" of the main male leaders of resistance to apartheid, and intrigued to discover Eleanor Kasrils, as a white woman, so committed to change. Francine, as a white South African, chose the biography of Bram Fischer because she wanted to see whether there were any white people who "made a difference". She had needed her "faith restored". Jabu was born as South Africa became a democracy and his personal interest in Thabo Mbeki was partly because they "came from the same area". But he also regarded Mbeki as a politically significant figure - a "political genius speaker" - who merited study because he also ran the country. Doris's study of Oliver Tambo was a route to finding out about the past, backgrounds and formative experiences of the leaders who she felt were currently subject to critical generalizations, including her own, e.g. of corruption.

\section{What was gained from the engagement with life stories?}

In the discussion, unasked, the students chose to compare their school and everyday knowledge of apartheid history with what they learnt from their engagement with the auto/biography. It became evident that besides their own reading, the experience of the "jigsaws", where each student reported to his or her peers, informed these responses.

There was consensus that this was a worthwhile set of tasks. This contrasted with their view of school as having provided a flat set of generalizations, racial stereotypes, broad, factual descriptions of apartheid and a limited focus - as resistance events - on Sharpeville in 1960 and Soweto on June 16, 1976. Mashudu described it as a "great exercise", Tertia said it was "a real learning experience", Francine described it as "invaluable" and Lungi commented that through it he gained great expertise on his topic.

In terms of expanded knowledge of apartheid resistance, Lungi found that the personal story of Hani took him through "other events contributing to freedom", most notably the daily realities of MK operatives - infiltrating, sabotaging, leaving. For Jabu, the study undermined generalizations by showing that "people were hit by apartheid in different ways and the way they resisted it, it also narrowed down to ... their personal experiences". He and a number of classmates noticed that different people, races and organizations 
had been involved in resistance. Rachel added that she had gained new respect for the role of overseas exiles in mobilizing resistance through sanctions. For Mashudu, it showed the "normal day to day people's reactions to laws" and the struggle as "inclusive" - as "what South African people were able to produce". Doris, from reading about Tambo, identified education as the key to a black elite having the voice and status to be leaders. She also was "excited" to see Tambo as a radical young activist and not just as the "intelligent old man" and "brains" behind the struggle. The trajectory of a life of resistance was observed.

What is striking is that, in reading in detail about one person's life, and then reporting on this to each other, students were adding texture and depth to their understanding of a historical era. It was more gendered, challenged simple racial dichotomies, paid more attention to the experiences of ordinary people, and recognized complexity in decision-making and in forms of action. What was not raised were differences in ideological positioning - the discourses of resistance.

As much as gaining information was useful to interviewees, what came across more strongly was an emotional engagement. The dominant sense was that life stories made the apartheid experience and resistance more "personal" and "more real" (Rachel). Jabu concluded that "apartheid affected everyone"; Tertia said that it went "much deeper" than she had thought - which is why "people today still feel such pain and suffering". Francine was struck by "how human Bram Fischer was" and how hard it must have been to deal with personal loss while "hectic national things were going on". Mashudu expressed surprise at his own feelings about the concurrent EFF "racial" and "radical" discourse (in the news) while he was "walking into the experience" of Eleanor Kasrils - "this ... white woman".

So as I was reading this book I was actually surprised because I found out ... that the people we blame for apartheid actually sacrificed certain things that I personally would not sacrifice. I would not leave ... my baby brothers and go and fight for somebody else's rights... I would find that it would be strange, to detach yourself from something you love so much for a cause that is not gonna benefit you in any way. It's gonna benefit you morally but physically you gonna be fine... It kinda shocked me in a way.

Jabu's respect for Mbeki was largely confirmed. This was despite (as he recognized through Gevisser's critique) "his flaws especially in leadership but ... they don't overpower what he stood for which was to serve the country because he poured, he put everything in. He put his heart into what he was doing". 


\section{Are there problems with focusing on great individuals?}

Could the students reflect on the implications of auto/biography as a historical construct? Interviewed a year after reading their books, some could not remember the author's name, but they were mostly sure that white South Africans wrote the biographies. Asmal's memoir was written with a white collaborator who Rachel thought was South African. Mashudu wrongly identified his book as an autobiography, which is a tribute to the vivid way in which Ronnie Kasrils represents his wife as "the unlikely secret agent".

I then asked:

Do you not think there is a problem with taking one or two good women and generalizing from them? ... Some historians are critical of focusing on great individuals ... especially as the famous people ... are the ones who get their biographies written. Have you got any views on that in the light of what you read? Does that make it any less valuable or is it just something to think about?

A number of students agreed that auto/biography could glorify an individual although Jabu recognized that Mbeki's did not. Lungi felt his biography was problematic because of this, with Francine agreeing that Clingman wanted to show Bram Fischer "as an exceptional man". Rachel commented that in collaborative writing, the author "could still get your sort of bias across". Nonetheless the students deployed their identities as historical thinkers in suggesting that the value of the biographies need not be nullified by their limitations. Mashudu said it was good to have undertaken the task in third year when they had acquired the "capacity" to deal with historical thinking through their academic and methodology classes. This refers to ongoing inclass discussion about the status of historical accounts, to their own local history research, and to the application of Wineburg's (2001) and Seixas and Peck's (2004) work on historical thinking in their methodology tasks.

Doris and Francine both pointed out that the stories reached beyond (glorious) individuals.

Granted Mandela can be on a pedestal or whoever, but at the end of the day those people still on the grassroots [were] still facing problems every day. But now what these biographies do for me, they break the boundaries across the colour lines to say there [were] different people at the same time, different colour, different perspectives, but going towards a certain goal, one goal...(Doris).

Through a life story, "more names" are heard and it is possible to see who else was involved with the central figure. Francine also felt that to generalize from Bram Fischer that: 
... every white male in apartheid was a saviour ... it's quite naïve and even ignorant. So... perhaps in reading a biography there does have to be some sort of responsibility in yourself to know, like I need to research this further if I'm going to start generalizing... And it won't take too long for me to see that I'm wrong.

For Tertia, the autobiography of a white woman resisting apartheid challenged a prior generalization but should not lead to a new one:

$[L]$ ike before we did this we had that generalization, black versus white. And now we can do the same generalization, but we stop ourselves because we describe one person; but that doesn't mean that every person like [Helen Suzman] stood up against it. Some people hid or some people just like accepted what was going on. So you can't generalize it either way.

Lungi's view of Chris Hani: A life too short was:

I feel like it was too glorified. Like you never get to hear the other side of him being the radical and the way the media portrays him... We get that one of being a fearless leader, very organized, very educated, like always having a book in fights and all those things. But we don't get to hear about him on a personal level, on other mistakes that he made, on other decisions that he makes. So I think that these biographies are also limiting our information (as Francine said), which we need to research more, to know about.

Agreeing that there was a bigger picture beyond the single biography, Lungi showed an awareness of the importance of who writes a life story. He had read a second, shorter book on Hani, which took the form of a friend's personal memoir. He distinguished between the perspective of Hani this provided and that based on "talking to people" and "research" which constituted the material for Chris Hani: A life too short.

I then raised the matter of biography as representation, commenting: "There is a push in historical writing to look at biography and autobiography, not as true histories, but as looking at the way people are representing themselves or are being represented by the author for a reason". This was taken up by Francine alone who agreed that Clingman may well have written his book differently if "he had a chip on his shoulder about Fischer". If someone else had written about Fischer would the story have been different? Francine continued:

It would be interesting to know more about the author ... because if I knew he was a relative or had heard [Fischer] at a lecture, or I don't know ... So it's interesting I think, to know why people are writing what they're writing and what's informing them and, you know, also as women ... if I have to research something ... there's a high chance if I can get a strong female who I can sort of punt and be like... then that would inform me... 
Mashudu saw his biography differently and argued that it showed the very strengths of the genre. "I think biographies and the overall understanding I've got from this is that let's focus on how the human experience of apartheid was." He alluded to Eleanor Kasril's time in prison, the hunger, the relegation to a mental asylum and the "emotion about it, the heart in it". To miss this would make the book "pointless". Tertia agreed because autobiography goes "deeper into the person". So the strength of biography, the students seemed to agree, was to bring humanity to the story of apartheid. Human vulnerability and pain could be perceived as well as or even despite heroic portrayals.

\section{The demands of the tasks}

The purpose of this set of tasks would have been invalidated by recourse to Internet summaries or skimpy popular vignettes of struggle leaders. I recognize that even at university, ours is not generally a reading culture, and was thus relieved to discover that all but two of the students had read their auto/biographies from beginning to end. Mashudu had no problem in finishing the relatively short biography of Eleanor Kasrils, which he found to be "dramatic" and "captivating". Francine had been living in Ireland after Grade 7 and appreciated the chance to fill in some gaps in her South African history. "It gave me a chance to find my own time to read a book that I chose, that I was interested in reading and to get to know more about my history".

For Jabu and Lungi reading the books had been a somewhat heroic event in their academic lives. Mastering the almost 900 pages of the Mbeki biography, Jabu said: "I got to see that I can actually manage my time. It was hard and tedious but each and every chapter ... was worth reading because I learnt more than I thought I knew about Thabo [Mbeki]." Lungi described his engagement:

Ja, I also read the whole book. It made me to be antisocial for weeks. Getting in the bus, having my earphones, reading, marking all what's important and all those things. I even went with it to home. Like at home ... people were thinking that I'm crazy. Every day I'm on my book. But ja, I finished it. It was tough, but I had to.

The two who did not complete their biographies are conscientious students and their comments confirmed what I have noticed in the past - that the need to analyse, as well as follow a life story, can hamper entry into the text.

HL: So what did you think of just the simple task of having to read a whole book like that? 
Rachel: It was challenging I think. But to get through ... I didn't get through the whole book because I think that just finding time to sit down and grapple with it was...

Doris: And you find that you have to go back to go and look for ...

Rachel: But it was interesting.

Doris: ... things ... and jot them down. You still have to mark and go back. It was a challenge.

Sam Wineburg (2001) reminds us that reading a historical text requires students to engage in a complex internal conversation as they seek to move below surface comprehension. A historical text presents them with multiple levels of meaning, issues of sourcing and corroboration, formal language (in a second language for many students), the author's subjectivity, the essential foreignness of the past, and changing contexts. I admire Doris's engagement with Callinicos's dense biography of Tambo, even if it was limited to the early years of his life!

The students least enjoyed writing (as an assessment task) an essay on one aspect of their subject's engagement in resistance. For some focusing on an appropriate event or issue out of the integrated whole of their subject's life was hard. For a number, finding relevant secondary sources as required for the essay proved difficult. Mashudu maintained, however, that this was "really needed" because different perspectives on the chosen episode were important.

What they all enjoyed was the "jigsaw" activity. It seems that the opportunity to share their newfound depth of knowledge with each other was highly valued. The reflections of the seven students in this focus group clearly reflected their learning from their peers as well, and Francine said she would have liked, time permitting, to have heard all (twenty-one) presentations. Lungi elaborated:

It was interesting to hear from other people and also to bring what I had. And it makes you an expert in what you are talking about because someone will come with what they know and you're sharing with the person. So now it's like a competition. I had to sound intelligent to this person. I thought, let me try by all means to take out everything I read. So I believe that also motivated us to go and read the whole books. Because it was going to be simple to go on the Internet and say this is the information. But to hear that someone is going to be listening to you, you have to be an expert of that book. [It] made us to be motivated and read these books. 


\section{Implications for teachers of school history}

The concluding discussion on whether they would use life stories in their own teaching of apartheid was fairly brief. The consensus was that a biographical approach would make the experience of apartheid and resistance to it "more real" for learners whose experience at school was that it was "very broad, impersonal and descriptive" (Rachel). Lungi felt it was important to teach about resistance as a collective effort by exposing learners to "different heroes of the struggle" ..."all those people"..." because a lot of kids will tell you, 'What's the use of us learning about apartheid because I'm going to hear about Mandela. He's in my money, there's a Mandela Square, there's everything."” Tertia and Francine tried to imagine how this approach could work in the classroom: perhaps through a number of PowerPoint presentations of different life stories (Tertia); perhaps through groups of four learners working together using important skills to research a life story and then presenting it to the class? The problem of working with difficult or superficial texts was recognized, with Mashudu returning to his view of the importance of developing the capacity for historical thinking:

You can't just go into the classroom and say, "here my grade 11 learners", and they battle in understanding historical concepts and critical thinking in terms of history. And just go "Okay, here's a textbook, read this textbook and here's an assignment like this." I think we have to foster people to have a capacity ... to actually deal with the content that autobiographies or biographies give to that person.

\section{Conclusion}

This interview with students, albeit brief, revealed their enthusiasm for reading the life stories of apartheid resisters. It showed perseverance, emotional connection and, for many, gratification that it exposed them to a more racially inclusive struggle narrative than they thought existed. While they were motivated to some extent by the desire for a "usable past" - one that met their present predispositions and needs, there was also evidence of an emergent historical perspective. Mashudu's impatience with "politicization" of struggle stories was related to his sense that there was more to be found the missing role of women. Tertia found herself cautious about replacing one generalization with another. Lungi had already referred to another book to see how or whether it corroborated what he found in Chris Hani:A life too short. Historical language used by students included "challenging generalizations", finding other "perspectives", needing to "take responsibility and research" 
further, and wondering how knowledge about authors might change their understanding of the text.

There are many aspects of student experience and understanding that I would like to probe further. What difference would their gender have made to apartheid resisters? Could students identify ideological positioning of their subjects more clearly? Are resisters presented as always consistent and coherent in their thoughts and actions? Could they have been? Can the life of a resister be reduced to this identity? To what extent could biographers or autobiographers have constructed narratives for a purpose that the students have not discussed? How do they deal with the truth claims of these books? Do students perceive lives of resistance lived many decades ago to be different from life lived in the present? How so?

The new historiographical trends - using biography to trace performances of multiple selves and to track flows of ideas and influences across the globe in new ways - invite me to ask different questions of students as they read their life stories. But most importantly, the desire to allow history to be a humanizing study encourages me to continue to let students meet the diverse people whose lives took them on fascinating, costly journeys of resistance to apartheid.

\section{References}

Asmal, K \& Hadland, A 2011. Politics in my blood - A memoir. Johannesburg: Jacana.

Callinicos, L 2004. Oliver Tambo: Beyond the Engeli Mountains. Cape Town: David Philip.

Clingman, S 2013. Bram Fischer: Afrikaner revolutionary, new ed. Johannesburg: Jacana.

Gevisser, M 2007. Thabo Mbeki: The dream deferred. Johannesburg: Jonathan Ball.

Kasrils, R 2010. The unlikely secret agent. Johannesburg: Jacana.

Margadant, JB, (ed.) 2000. The new biography: Performing femininity in nineteenth-century France. Berkeley \& Los Angeles: UC Press.

Mandela, N 1994. Long walk to freedom: The autobiography of Nelson Mandela. Randburg, SA: Macdonald Purnell.

Macdonald, A 2013. Transnational history: A review of past and present scholarship. UCL Centre for Transnational History, 2013. Available at https://www.ucl.ac.uk. 
Accessed on 7 July 2015.

McKenzie K 2008. Review of D Lambert \& A Lester (eds.). Colonial lives across the British empire: Imperial careering in the long nineteenth century. New York: Cambridge University Press. In American historical review, February 2008, pp. 145-146.

Ngai, MM 2012. Promises and perils of transnational history, Perspectives on history, December 2012. Available at https://www.historians.org. Accessed on 7 July 2015.

Seixas, P \& Peck, C 2004. Teaching historical thinking. In: A Sears \& I Wright (eds.). Challenges and prospects for Canadian Social Studies, Vancouver: Pacific Educational Press, pp. 109-117.

Sisulu, E 1997. Walter \& Albertina Sisulu: A biography. Cape Town: David Philip.

Smith, J \& Tromp B 2009. Chris Hani: A life too short. Johannesburg: Jonathan Ball.

Suzman, H 1993. In no uncertain terms: A South African Memoir. New York: Knopf.

Thelen, D 2002. How the Truth and Reconciliation Commission challenges the ways we use History. South African Historical Journal, 47(1):162-190.

Wineburg, S 2001. Historical thinking and other unnatural acts: Charting the future of teaching the past. Philadelphia: Temple University Press.

\section{Appendix A:}

\section{Examples of resisters whose auto/biographies have been used}

Kader Asmal

Frances Baard

Lionel Bernstein

Steve Biko

Patricia de Lille

Ruth First

Chris Hani

Trevor Huddleston

Helen Joseph

Eleanor Kasrils

Ronnie Kasrils

Ahmed Kathrada

Ellen Kuzwayo

Albert Luthuli

Nokukanya Luthuli

Nelson Mandela

Winnie Mandela 


Trevor Manuel
ZK Matthews
Ismail Meer
Kgalema Motlanthe
Jay Naidoo
Beyers Naude
Lillian Ngoyi
Phyllis Ntantala
Alan Paton
Cyril Ramaphosa
Mamphela Ramphele
Maggie Resha
Albie Sachs
Walter \& Albertina Sisulu
Robert Sobukwe
Helen Suzman
Oliver Tambo
Ahmed Timol
Desmond Tutu.
Donald Woods

\section{Appendix B: Interview schedule for History Focus Group, 2015}

\begin{tabular}{|c|l|l|l|}
\hline 1. & Main Question & Possible Probe Questions & Reasons for asking them \\
\hline $\begin{array}{l}\text { What was the title and } \\
\text { of the auto/biography } \\
\text { that you read? Can you } \\
\text { remember when it was } \\
\text { written? }\end{array}$ & $\begin{array}{l}\text { If you read a biography, did } \\
\text { the author know the subject } \\
\text { personally? Was the author the } \\
\text { same gender, race, nationality } \\
\text { as the subject? }\end{array}$ & $\begin{array}{l}\text { To elicit basic information } \\
\text { while starting the conversation. } \\
\text { It will also be relevant } \\
\text { when thinking about the } \\
\text { construction of a historical } \\
\text { identity in Q 4. }\end{array}$ \\
\hline 2. & $\begin{array}{l}\text { What were the reasons } \\
\text { for your choice of the } \\
\text { subject of this book? }\end{array}$ & $\begin{array}{l}\text { Did you identify with this } \\
\text { person? Did you want a } \\
\text { different perspective from } \\
\text { your own? Had you heard of } \\
\text { him/her before? Any reason } \\
\text { for choosing a man, woman, } \\
\text { member of a particular } \\
\text { organization etc? }\end{array}$ & $\begin{array}{l}\text { To try to understand personal } \\
\text { motivation and choices of } \\
\text { students. }\end{array}$ \\
\hline
\end{tabular}




\begin{tabular}{|c|c|c|c|}
\hline 3. & $\begin{array}{l}\text { What do you think you } \\
\text { gained from reading this } \\
\text { book and studying the } \\
\text { life of this person? }\end{array}$ & $\begin{array}{l}\text { What surprised you? What } \\
\text { aspect of this person's life and } \\
\text { struggle had the most impact } \\
\text { on you? Did it alter in any } \\
\text { way your understanding of } \\
\text { apartheid and resistance? Some } \\
\text { students express weariness or } \\
\text { other emotions at having to } \\
\text { study apartheid (again) -how, } \\
\text { if at all, do you think reading } \\
\text { this auto/biography influenced } \\
\text { your feelings about this topic, } \\
\text { era or issue? }\end{array}$ & $\begin{array}{l}\text { This is the central question } \\
\text { and the intention is to allow } \\
\text { students to open up on the } \\
\text { discussion as they choose. I am } \\
\text { interested in both intellectual } \\
\text { and affective responses. }\end{array}$ \\
\hline 4. & $\begin{array}{l}\text { Some historians are } \\
\text { critical of focusing on } \\
\text { 'great individuals' and } \\
\text { on presenting a person's } \\
\text { life and character as } \\
\text { uncontested. Have you } \\
\text { any views on this in } \\
\text { the light of the auto/ } \\
\text { biography you read? }\end{array}$ & $\begin{array}{l}\text { Do you think another author } \\
\text { would have interpreted your } \\
\text { subject's life differently? Why? } \\
\text { Why not? What sources of } \\
\text { information for this life story } \\
\text { do you think the author used? } \\
\text { Did you think about that as } \\
\text { you read the book? To what } \\
\text { extent do you think your } \\
\text { subject was contextualized/ or } \\
\text { contextualized him/herself in } \\
\text { the society and wider resistance } \\
\text { movements of the time? What } \\
\text { was the purpose of the book? }\end{array}$ & $\begin{array}{l}\text { To explore students' critical } \\
\text { awareness of auto/biography } \\
\text { as history. 'New' biography is } \\
\text { engaged with representation } \\
\text { rather than truth, so I am } \\
\text { heading in that direction with } \\
\text { this discussion. }\end{array}$ \\
\hline 5. & $\begin{array}{l}\text { Was there anything a } \\
\text { future history teacher } \\
\text { could take both from } \\
\text { reading the life story } \\
\text { of an apartheid resister } \\
\text { and the activities linked } \\
\text { to it in the History } 3 \\
\text { module? }\end{array}$ & $\begin{array}{l}\text { Was the reading task an } \\
\text { obstacle for you? What if } \\
\text { anything can a focus on } \\
\text { one episode in the subject's } \\
\text { life show (as tackled in the } \\
\text { essay)? Was it possible to learn } \\
\text { anything from the jigsaw } \\
\text { exercise? Please give reasons for } \\
\text { your answers. }\end{array}$ & $\begin{array}{l}\text { To see whether there is } \\
\text { evidence of the careful thought } \\
\text { that recontextualization of } \\
\text { what is learnt in an academic } \\
\text { history course requires before } \\
\text { transfer to a school classroom } \\
\text { takes place. }\end{array}$ \\
\hline
\end{tabular}

